\title{
The Effect of Ultrasonic Wave Exposure on The Chlorophyll-a, b And Carotene Content of Nannochloropsis sp.
}

\author{
Hadi Endrawati, Muhammad Zainuri, Widianingsih, Retno Hartati*, Robertus Triaji \\ Mahendrajaya, Sri Redjeki, Ita Riniatsih, Ria Azizah
}

\author{
Marine Science Department, Faculty of Fisheries and Marine Science, Diponegoro University \\ Jl. Prof. Soedharto, SH. Tembalang. Semarang 50275. \\ E-mail: retnohartati.undip@yahoo.com
}

\begin{abstract}
Determination of chlorophyll-a, b and carotene content in microalgae is strongly dependent on the destruction of its cell wall during extraction process. Harvesting of microalgae is important because it will influence the nutrition content. The objective of present work is to optimize harvesting of Nannochloropsis sp by application of ultrasonic wave with frequency of $40 \mathrm{KHz}$ under different exposure time. There were 3 treatments, i.e. exposure time of 5, 10 and 15 minutes. The chlorophyll-a, $b$, and carotene content were measured to gauge the effect of treatments. The result revealed that the cell wall of Nannochloropsis sp which made from carbohydrate were successfully broken by ultrasonic source equipment. It showed that the exposure time of 5,10 and 15 minutes affected cell wall's breaking percentage of Nannochloropsis sp cell by 10,$35 ; 32,15$; and $72,09 \%$, respectively. The longer exposure time of ultrasonic wave, the higher content of chlorophyll-a, b, and carotene.
\end{abstract}

Keywords: cell wall; exposure; time; pigment; sonication

\section{INTRODUCTION}

Microalgae are microorganism with a simple structure yet are highly diverse. Their heterogeneity is conditioned by a number of characteristics, including the place of occurrence, the level of organization of the cell, the type of pigments, size, or metabolic pathways (Piasecka et al., 2014). They have potency to be developed as functional food for human. In the field of aquaculture, microalgae are also important as sources of nutrients, producing oxygen, absorbing carbon dioxide and consuming nitrogencontaining compounds (Perez-Garcia et al., 2011)

The Utilization of microalgae is influenced by its harvesting process. Pretreatment of biomass and sample preparation are important steps. Several methods have been applied to break the cell walls of microalgae in order to extract the maximal result. Mechanical, chemical, and enzymatic methods are most widely used for cell disintegration in microorganism biomass. Halim et al. (2012a) conducted pretreatments during harvesting process, i.e. drying the concentrate of microlagae and then milled into powder. The breaking of cell walls in microalgae could also be carried out using mechanical collisions (Dere et al., 1998), microwaves $\left(100{ }^{\circ} \mathrm{C}\right)$, autoclaving (121-125 ${ }^{\circ} \mathrm{C}$ ), and sonication (Gerde et al., 2012) The study of sonication effects in energy produced by intercellular of microalgae has been conducted by (Gerde et al., 2012), although the microalgae sonication can produce free radicals that can affect the quality of the oil produced by the formation of lipid hydroperoxides. Ultrasound utilization has also been applied to the breaking maize particles in effort to increase the content of hydrolysis enzymes (Khanal et al., 2007). Ultrasonication and microwave are distinguished among the treatments. It is important that most methods used to disrupt cells demand a small amount of water in algal biomass for successful cell disintegration (Halim et al., 2012a). It is expected that the application of 
sonication to the breaking of cells can also save the electrical energy normally used for grinding and increase the quality of the resulted material. Cell disruption (sonication and microwave) techniques were used by Piasecka et al. (2014) to improve lipid extraction from wet biomass. They showed that wet biomass after sonication is the most suitable for extraction.

Pigment is a widely known compound used as a natural dye in the world of industry and health. Pigments derived from the carotenoid group, are potentially applicable to the medical field, as one of them being recognized as a source of anti-cancer compounds. In addition to herbs, marine microalgae can also become a potential source of such carotenoid pigment.

The arising problem in producing marine microalgae to support the commercial microalgae industry occurs during post-harvest handling process. One of the problems is the utilization of chemical substances such as $\mathrm{NaOH}$ as flocculation compound during the breaking of microalgae cell walls, as well as mechanical hilt in microalgae harvesting process. This study is aimed to optimize disruption of Nannochloropsis sp. cells by applying different time of exposure of ultrasonic waves at a frequency of $40 \mathrm{Khz}$.

\section{MATERIALS AND METHOD}

Mono culture of microalgae
Nannochlorosis sp. is obtained from
Brackishwater Aquaculture Research
Development Centre, Jepara. The ultrasonic
wave transmitter circuit is operated with
voltage DC +5 volt up to DC +25 volts. The
series of ultrasonic wave transmitters above
has working frequency determined by the
configuration values of R1, R3 and R2, R4 with
C1 (condenser 100 nF). Potensiometer R3 is
functioned as a positive side pulse controller
while R4 potentiometer is served as a
negative side pulse controller. The area and
the pulses of positive and negative
generated by the astax multifibrator IC555
are controlled by potentiometers R3 and R4.
The high and low pulses resulted by the IC555
multivibrator will move the ultrasonic
transducer.

Cultures of Nannochloropsis sp. were placed in erlenmeyer flask size of $250 \mathrm{ml}(100$ $\mathrm{ml}$ medium $+50 \mathrm{ml}$ inoculum microalgae), aerated, keep in $25{ }^{\circ} \mathrm{C}$ room temperature and using $30 \mathrm{watt} / \mathrm{m}^{2}$ light irradiance. Conway fertilizer was used with concentration of $1 \mathrm{ml}$ liter-1 of culture medium. The density of microalgae was observed every day. When entering the stationary phase, the microalgae were harvested and challenged to ultrasonic wave exposure time with frequency of $40 \mathrm{KHz}$ at different exposure time, i.e. 5, 10 and 15 minutes. The treatments were triplicated. After being treated, the microlagae was underwent the following analyses (Dere et al., 1998). A hundred $\mathrm{ml}$ of microalgae was harvested, filtered and weighed. The sample then was added with $10 \mathrm{~mL}$ of $96 \%$ aceton, homogenized with the B-Brawn type homogenizer at $1000 \mathrm{rpm}$ for one minute. The homogenate was filtered through two layers of cheese cloths, and was centrifuged using the Nüve Füj 650 model centrifuge at 2500 rpm for ten minutes. The supernatant was separated and the absorbances were read at $400-700 \mathrm{~nm}$ on Schimadzu UV-260 spectrophotometer The absorbance was measured at wavelengths of $470,630,645$, $662,663,665$ and $750 \mathrm{~nm}$, with the blank solution of $96 \%$ Aceton. It was recorded that Chlorophyll a showed the maximum absorbance at $662 \mathrm{~nm}$, chlorophyll b at 646 $\mathrm{nm}$ and total caroten at $470 \mathrm{~nm}$. After reading the absorbance at each wavelengths, the contents of Chlorophyll -a, $b$, and the total of carotene were determined using the following equations by Lichtentaler and Wellburn (1985).

\section{RESULTS AND DISCUSSION}

Nannochlorosis sp. which belongs to the phylum Chlorophyta, is well appreciated in aquaculture due to its nutritional value and the ability to produce valuable chemical compounds, such as pigments and polyunsaturated fatty acids (EPA) (Rocha et al., 2003). This phyllum is well known as a source of different valuable pigments, such as chlorophyll a, zeaxanthin, canthaxanthin and astaxanthin (Lubia'n et al, 2000), which are produced at high levels.

In this study, cell counting was carried out every day to know the density of the 
microlagae and to get their growth pattern. The microalgae growth followed several phases, i.e. induction, exponential, stationary and death phase. The phase of microalgae depends on the species. During the initial of exponential phase, the process of cell division took place rapidly, so the microalga growth formed a linear pattern. The rate of growth depends on the species of microalgae, light intensity, medium temperature and the nutrients. In the end of exponential phase, the cell growth rate is relatively decreased, during this phase nutrient content was decreased. Therefore they were harvested in the exponential phase at day five.

Before being used for biocommodities, micro algae which has been cultured have to be harvested, dewatered, and extracted. The efficacy of those steps (growth, harvesting, dewatering, and extraction) depends upon the composition and architecture of the cell wall (Scholz et al., 2014). The wall creates a buffer between the external environment and the living protoplast, protecting the cell from environmental pressures. The outer surface of the wall interacts with flocculants (Cheng et al., 2011), and its rigidity helps determine the

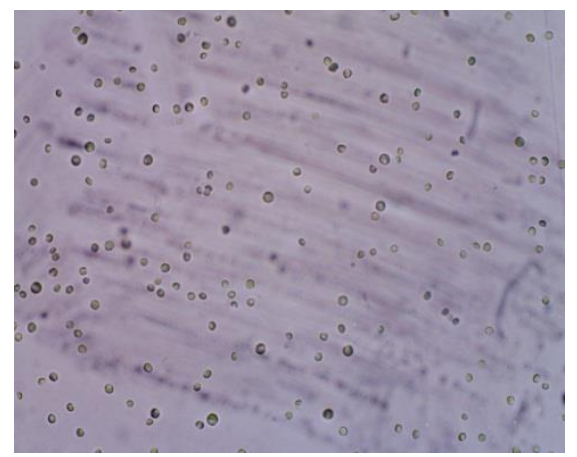

(a) viscoelastic parameters that characterize algal slurry bulk flow (Adesanya et al., 2012). Finally, the cell wall erects mass transfer barriers against dewatering and extraction and may itself contain extractable commodities (Eggers et al., 1985; Sowbhagya et al., 2013). Mechanical method such as ultra-sonication is most widely used for cell disintegration in microorganism biomass (Halim et al., 2012a).

The result of sonication at different exposure time showed that there was a significant difference to the breaking of cell wall in various types of microalgae. Nannochloropsis sp has high chlorophyll-a, b and carotenoid pigment content compared to other microalgae types. This corresponds to an image showing Nannochloropsis sp cells damaged at exposure to 15-minutes ultrasonic waves compared with no exposure (Figure 1)

The percentage of cell wall breaking of Nannochloropsis oculata showed the highest value of $70.09 \%$ after 15 minutes exposure, followed by $32.15 \%$ and $10.35 \%$ after 10 and 5 minutes exposure time, respectively. The magnitude of the percentage of cell

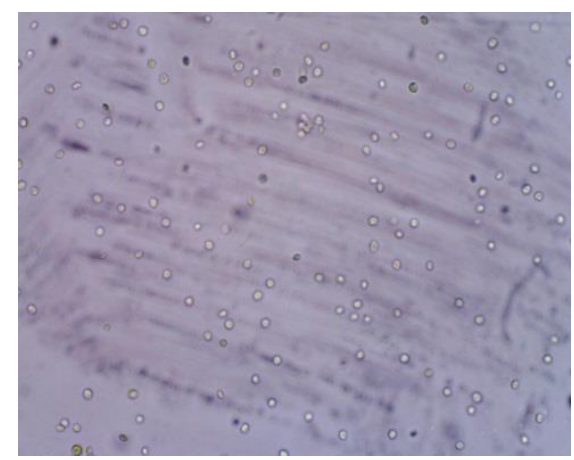

(b)

Figure 1. (a) Nannochloropsis sp without ultrasonic exposure and (b) after being exposed to ultrasonic waves for 15 minutes

Table 1. The content of chlorophyll-a, b and Carotenoids in microalgae Nannochloropsis sp. with a long treatment time of $40 \mathrm{~Hz}$ ultrasonic wave exposure.

\begin{tabular}{lcccc}
\hline \multirow{2}{*}{ Content of } & \multicolumn{4}{c}{ Duration of } \\
\cline { 2 - 5 } & Kontrol & 5 minute & 10 minute & 15 minute \\
\hline Chlorofil-a & 0.22 & 0.22 & 0.38 & 0,53 \\
Chlorofil-b & 0.12 & 0.12 & 0.33 & 0.47 \\
Carotene & 0.15 & 0.15 & 0.32 & 0.77 \\
\hline
\end{tabular}


wall due to the destructing process by the sonication treatments of the Nannochloropsis oculata microalga indicates that the microalga is rapidly damaged. This is also demonstrated by the research material from (Abbassi et al., 2014) which suggests there is the breaking of cell walls using liquid nitrogen treatment and hydraulic pressure.

\section{Chlorophyll-a, Chlorophyll-b and Carotene content of Nannochloropsis sp.}

Chlorophyll-a content in microalgae of Nannochloropsis sp. at various times to ultrasonic wave exposure of 5, 10, 15 minutes and control (without ultrasonic wave exposure) are presented in Table 1. Based on observation, in the chlorophyll-a content of the microalgae after being exposed to utrasonic waves with frequency for 15 minutes showed that the exposure showed the analysis result of higher chlorophyll-a, $b$ and carotene compared with microalgae without ultrasonic wave exposure at a frequency of $40 \mathrm{KHz}$. Sonication uses cavitation waves induced by ultrasounds in the solution. This is related to the fact that the continuity of microalgal cell walls is disrupted (Piasecka et al., (2014). Whilst microwaves induce an electromagnetic effect, which affects cell wall thickness destroys microalgal cells. Prabakaran and Ravindran (2011) compared the effect of the cell disruption method on lipid extraction for three microalgal species (Chlorella sp., Nostoc sp. and Tolypothrix sp.) and observed the highest lipid content in the sonication method. Their study suggested that the sonication method was the most suitable for large-scale lipid extraction from microalgae. Furthermore, the microwave method was also efficient among the techniques that they used. It could be concluded from this result that the cell wall should be destroyed for efficient oil extraction. Also, Suganya and Renganathan (2012) reported that ultrasonic pretreatment improved lipid extraction more than microwave pretreatment. During extraction with cell disruption techniques, the choice of the solvent was not relevant. However, Halim et al. (2012b) suggested that the level of cell disruption during sonication could be species dependent. Both extraction methods were slightly more efficient after applying cell disruption techniques. Suganya and Renganathan (2012) reported that ultrasonic pretreatment improved lipid extraction more than microwave pretreatment.

Cell disruption methods improved the efficiency of lipid extraction (Piasecka et al. 2014). The ultrasonic pretreatment caused the highest increase in crude oil. The ultrasonic and microwave pretreatment caused an increase in the palmitic acid content in the fatty acids profile. Both methods induced changes in the ratio of unsaturated to saturated fatty acids. Lipid extraction from wet microalgal biomass after sonication is an alternative to the commonly used methods of lipid recovery.

It is worth noting that in the microwaveassisted method, the content of saturated fatty acids (C16:0 and C18:0) increased while the content of unsaturated fatty acids such as C18:1, C18:2, and C18:3 decreased. Especially, it is evident in the chloroform: methanol extraction. A similar result was obtained by Cheng et al. (2013). They argue that the electromagnetic effect and heat rapture unstable bonds in a carbon chain and change the structure. Microwave as a cell disruption technique improves extraction of crude oil, regardless of the influence on the fatty acid profile. Similar results were obtained in the sonication-assisted method of extraction. The content of saturated fatty acids increased while the yield of unsaturated fatty acids (C18:1 and C18:3) decreased. Based on previous considerations, the decline may result from breakdown of unstable bonds. Breaking of unstable bonds occurs as a result of the energy produced during sonication.

\section{CONCLUSION}

The length of time of exposure greatly affects the content of chlorophyll-a, $\mathrm{b}$ and Carotenoids. The longer the exposure time is, the higher the content of chlorophyll-a, $b$ and Carotenoid.

\section{REFERENCES}

Abbassi, A., M. Ali and A. Watson. 2014. Temperature dependency of cell wall 
destruction of microalgae with Liquid Nitrogen pre-treatment and hydraulic pressing. Algal Research. 5:190-194.

Adesanya, V.O., Vadillo, D.C. \& Mackley, M.R. 2012. The rheological characterization of algae suspensions for the production of biofuels. J. Rheol. 56:925-939. DOI : 10.1122/1.4717 494.

Cheng J., Sun J., Huang Y., Feng J., Zhou J., \& Cen K., 2013. Dynamic microstructure and fractal characterization of cell wall disruption for microwave irradiation assisted lipid extraction from wet microalgae. Biores. Technol. 150:67-72.

Cheng Y-S, Zheng Y, Labavitch JM, VanderGheynst JS. 2011. The impact of cell wall carbohydrate composition on the chitosan flocculation of Chlorella. Process Biochem. 46:1927-1933. DOI : 10.1016/j.procbio.2011.06.021.

Dere, S., T. Gunes, and R. Sivaci. 1998. Spectrophotometric Determination of Chlorophyll -A, B and Total Carotenoid Contents of Some Algae Species Using Different Solvents. Tr. J. Botany 22:13-17

Eggers R, Sievers U, Stein W. 1985. High pressure extraction of oil seed. J. Am. Oil Chem. Soc. 62:1222-1230. DOI : 10.1007 /BF02541832.

Gerde, J.A., M.M. Lomboy., L. Yao., D. Grewell and T. Wang. 2012. Evaluation of microalgae cell disruption by Ultrasonic Treatment. Biores. Technol. 125:175-181.

Halim R., Danquah M.K., and Webley P.A., 2012a. Extraction of oil form microalgae for biodiesel production: a Review. Biotechnol. Adv., 30:709-732.

Halim R., Harun R., Danquah M.K., and Webley P.A., 2012b. Microalgal cell disruption for biofuel development. Appl. Energ. 91:116-121.

Khanal, S.K., Montalbo, M., Van Leeuwo, J., Srinivasan, M. \& Grewell, G., 2007. Ultrasound Enhanced Glucose Release from Corn in Ethanol Plant. Biotechnol. Bioeng. 98:978-985.
Lubián, L., Montero, O., Moreno-Garrido, I., Huertas, I.E., Sobrino, C., González-del Valle, M. \& Parés, G. 2000. Nannochloropsis (Eustigmatophyceae) as source of commercially valuable pigments. J. Appl. Phycol. 12:249-255. DOI : 10.1023/A:100 8170915932.

Perez-Garcia, O., F.M.E. Escalante, L.E. DeBashan, Y. Bashan. 2011. Heterotrophic Cultures of Microalgae Metabolism and Potential Products. Water Res. 45:11-36.

Piasecka, Agata., Izabela Krzemiñska, and Jerzy Tys. 2014. Physical methods of microalgal biomass pretreatment. Int. Agrophys. 28:341-348

Prabakaran P. and Ravindran A.D., 2011. A comparative study on effective cell disruption methods for lipid extrac-tion from microalgae. Lett. Appl. Microbiol., 53(2) 150-154.

Rocha J.M.S., Juan E C Garcia, Marta Henriques. 2003. Growth aspects of the marine microalga Nannochloropsis gaditana. Biomol. Eng. 20(4-6):237-42. DOI: $10.1016 / 51389-0344(03) 00$ 061-3

Scholz, M.J., Taylor L. Weiss,b Robert E. Jinkerson, a Jia Jing,c Robyn Roth, d Ursula Goodenough,b Matthew C. Posewitz, a Henri G. Gerkene 2014. Ultrastructure and Composition of the Nannochloropsis gaditana Cell Wall. Eukaryotic Cell 13(11): 1450-1464. DOI :10.1128/EC.0018314

Sowbhagya H, Sushma SB, Rastogi N, Naidu MM. 2013. Effect of pretreatments on extraction of pigment from marigold flower. J. Food Sci. Technol. 50:122-128. DOI : 10.1007/s13197-011-0313-4.

Suganya T. and Renganathan S., 2012. Optimalization and kinetic studies on algal oil extraction from Marine macroalgae Ulva lactuca. Biores. Technol. 107:319-326. 